\title{
O Brasil na França pelas lentes de Samuel Costa
}

\author{
Marcos André Galdino \\ MORAIS
}

\section{Resumo}

A proposta dessa pesquisa é analisar a produção fotográfica de Samuel Costa, goiano, morto precocemente em 1987 aos 33 anos, especificamente as imagens do Brasil que ele veiculou na Europa entre 1980 e 1985, quando viveu na França. O trabalho envolve, num primeiro momento, a identificação, catalogação e digitalização das fotografias produzidas por Samuel Costa nesse período dentro da temática escolhida para estudo, a partir de consulta ao acervo da família. O objetivo principal da pesquisa é investigar a estética documental dominante na fotografia brasileira do período, a partir da análise das fotografias de Samuel Costa. Com isso, pretendemos observar no trabalho produzido pelo fotógrafo a presença, sobretudo, de uma visualidade que evidencia questões de identidade e a criação ou não de processos que apontam para novas sintaxes visuais no contexto da produção fotográfica documental do período. Essa pesquisa pretende ainda contribuir para os estudos referentes à história da fotografia em Goiás, bastante incipientes, resgatando e divulgando a produção fotográfica de Samuel Costa.

Palavras-chave: fotografia documental, Samuel Costa, história da fotografia. 